\title{
Centaurs and Lapiths in the landscape of Thessaly
}

Book or Report Section

Accepted Version

Aston, E. (2017) Centaurs and Lapiths in the landscape of

Thessaly. In: Hawes, G. (ed.) Myths on the map: the storied landscapes of ancient Greece. Oxford University Press. ISBN 9780198744771 Available at

http://centaur.reading.ac.uk/57616/

It is advisable to refer to the publisher's version if you intend to cite from the work. See Guidance on citing.

Publisher: Oxford University Press

All outputs in CentAUR are protected by Intellectual Property Rights law, including copyright law. Copyright and IPR is retained by the creators or other copyright holders. Terms and conditions for use of this material are defined in the End User Agreement. 


\section{CentAUR}

Central Archive at the University of Reading

Reading's research outputs online 


\title{
Centaurs and Lapiths in the Landscape of Thessaly ${ }^{1}$
}

\author{
Emma Aston
}

\section{Introduction}

Lapiths and Centaurs are some of the most ubiquitously visible figures of Greek myth. In antiquity, a visitor to the Athenian Acropolis would have seen them fighting in furious pairs on the metopes of the Parthenon; if he travelled in the Peloponnese he would have encountered them again on temples at Olympia and Bassai. If he drank from an Attic winecup, perhaps the combatants appeared on its red and black surface, the Centaurs wielding rocks and pine-branches, the Lapiths swords.

Plainly the myth was on some level highly mobile, able to move between regions and find meaning and power in different places and situations. To some extent, this mobility must have derived from the strong symbolic associations which Lapiths and Centaurs could convey, associations which spanned great tracts of ancient literary and visual culture in a cumulative evocation upon which authors and craftsmen could draw. ${ }^{2}$ Moreover, their symbolic potency was shared by their homeland, Mount Pelion in Thessaly, one of the 'imaginary mountains' of Greek myth, whose power as a mise-en-scène has been established by the work of Richard Buxton. ${ }^{3}$ Imaginary Lapiths and Centaurs on an imaginary mountain: this is certainly an important dimension of the myth.

It is, however, vital not to lose sight of the fact that the region of Mount Pelion was also a real place. Thessaly was not always the easiest place to travel through, and yet trade, war and diplomacy took other Greeks to and through the region frequently. Thessaly was not experienced by other Greeks solely through its stories, but also through direct exposure to its landscape, a landscape in which Mount Pelion, looming on the eastern seaboard, was a dominant feature. Thessaly and Pelion were not purely imaginary.

Thessaly also, of course, had its own inhabitants. Myths such as those of the Centaurs and the Lapiths were not simply imposed on Thessaly, having first been concocted outside

\footnotetext{
${ }^{1}$ I am grateful to the volume editor Greta Hawes for her exceptionally helpful and insightful comments on this paper. All remaining errors are of course my own.

${ }^{2}$ For an extensive recent treatment, see Bremmer (2012).

${ }^{3}$ Buxton (1992) and (1994) 92-5.
} 
the region; they were formed in, and shaped by, the landscapes in which they are set. It is this local perspective which this chapter seeks to restore. It argues against the implicit tendency to present Thessaly in a passive light as the setting of stories, the canvas on which they were drawn by more adept hands. We should see Thessalian communities as dynamic participants in those stories' development - moreover, as participants in contact and conversation with wider strands of cultural and intellectual activity.

$>$ Map 1 here $<$

\section{Thessaly: one land or many?}

As far as possible, this chapter will identify the involvement of specific local communities within Thessaly. This is especially important when studying a region whose political and cultural unity was fairly loose. Some myths - such as that of the hero Thessalos - clearly had regional force, but this should not blind us to the amount of variation and fragmentation that simultaneously pertained. The Thessaloi were an ethnos, and would have identified themselves as such; however, material and epigraphic evidence in particular reveals a patch-work of sub-regional identities that roughly accord with demarcations of geography. Thessaly's two plains, east and west, show significant differences of religion, dialect and material culture $;^{4}$ the plains were divided into four tetrads or districts, Pelasgiotis, Thessaliotis, Hestiaiotis and Phthiotis; ${ }^{5}$ within these, specific poleis cultivated their own deities, rituals and political habits. ${ }^{6}$ Add to this the so-called perioikic regions around Thessaly (most notably Magnesia on the eastern side, ${ }^{7}$ Achaia to the south and Perrhaibia to the north), periodically subordinate to major settlements in plainland Thessaly, ${ }^{8}$ and it becomes clear that a failure to accommodate variety would be injurious to the effectiveness of this discussion. That said, it would be equally mistaken to posit too sharp a divide between 'Thessaly proper' (essentially, the land of the plains) and the perioikic regions. As

\footnotetext{
${ }^{4}$ Mili (2015) 179-85.

${ }^{5}$ On the tetrads, see Harpokration s.v. $\tau \varepsilon \tau \rho \alpha \rho \chi i ́ \alpha$ (quoting Hellanikos FGrHist 4 F 52; Aristotle fr. 497 Rose). For discussion, see Sprawski (1999) 17-23, and the far more complex and controversial treatment in Helly (1995) 150-91 and passim.

${ }^{6}$ For a recent assertion of the importance of the polis in Thessalian life, see Mili (2015) 8-10.

${ }^{7}$ For a full and recent discussion of Magnesian history and society, see Helly (2014).

${ }^{8}$ Thucydides calls the Perrhaibians $\dot{\pi}$ íkoor - subordinates - of the Thessaloi (see further on p. xxx); the same term is used of the Phthiotic Achaians at 8.3.1. On the perioikic regions: Graninger (2011) 13-19. On the relationship between Thessaly and its immediate neighbours, see Sprawski (2006).
} 
this chapter will show, myth constantly ranged between the two, and its purpose was sometimes to reflect on their interrelationship.

\section{Geography and tribal politics in non-Thessalian accounts}

If one looks at the substantial ancient accounts of the conflict between Lapiths and Centaurs, it is immediately striking how spatially grounded most of them are. Rather than emphasising the anatomical strangeness of the Centaurs, such narratives present them as one tribe among many, their hybridism frequently downplayed in order to place them within a narrative of territorial displacement and acquisition.

The presentation of the Lapiths and the Centaurs as two tribes fighting for control of specific Thessalian territory is not merely a product of the kind of post-Classical mythographic rationalism which one finds in the works of many ancient mythographers, a stripping out of the fantastic and the otherworldly: ${ }^{9}$ in fact a similar presentation is found in Homer, in the Catalogue of Ships (Il. 2.738-747).

And those who held Argissa and lived in Gyrtone, Orthe, Elone, and the white city of Oloösson, these were led by Polypoites staunch in battle, the son of Peirithous whom immortal Zeus conceived; renowned Hippodameia bore Polypoites to Peirithous on the day when he got revenge on the shaggy Beasts, drove them from Pelion and forced them into the vicinity of the Aithikes.

Thus is established a motif which subsequently appears in several major accounts of the conflict: the displacement of the Centaurs from their mountain stronghold of Pelion. Their destination sometimes varies in later accounts; here they are pushed westward towards the territory of the Aithikes, a Pindos people whom Strabo (7.7.9) treats as historical and current rather than fictional or obsolete. More importantly, the passage from the Catalogue of Ships establishes the land controlled by the Lapiths, and this emerges as quite a coherent area of territory centred on the course of the river Peneios and extending (in the case of Oloösson) up

\footnotetext{
${ }^{9}$ For a detailed recent analysis of the phenomenon of rationalisation in Greek mythography, the literary strategy of producing 'a new version of the traditional story which preserves elements of the original while adhering to a stricter standard of possibility', see Hawes (2014, quotation from p. 3).
} 
into the mountains of Perrhaibia. The importance of the Peneios as unifying the 'Lapith zone' of Thessaly is expressed in the mythical role of Stilbe, mother of the eponymous ancestor Lapithes and daughter of the river Peneios himself (Diod. Sic. 4.69.1). While the Centaurs are characterised by their mountain haunt (which they lose), the Lapiths have a more diffuse localisation along and around the eastern section of a long and winding river that gave the plain of Pelasgiotis its vital agrarian and pastoral fertility.

This sense of the respective territories of the two tribes is expanded in the narrative of Strabo, large sections of whose work read like a commentary on the Catalogue of Ships. The Thessaly section in Book Nine is no exception: the selection and ordering of the sites, and the information offered for each, is governed by the Catalogue and by Strabo's desire to relate it to the settlements and the landscape of his present day in the late first century BC and early first century AD. ${ }^{10}$ Thessaly, as homeland of Achilles and of other important epic heroes, excites his special notice and provokes a more detailed and complex account than the region tends to be accorded in ancient texts.

The fullest description of the Centaurs and the Lapiths is as follows (Strabo 9.5.19):

Adjacent to this part are those described as the subjects of Polypoites: 'those who held Argissa and lived in Gyrtone, Orthe, Elone, and the white city of Oloösson.' At an earlier time the Perrhaibians inhabited this land, cultivating the part near the sea and near the Peneios up to its outlet and to the Perrhaibian city of Gyrton. Then the Lapiths humbled them and occupied their territory - Ixion and his son Peirithous, who took possession of Pelion by forcing out the wild tribe of the Centaurs who held it. These he 'drove from Pelion and forced into the vicinity of the Aithikes'; but he handed over the plainland to the Lapiths. A certain part of that land the Perrhaibians occupied, the part near Olympos; and in fact there are areas where they lived entirely intermingled with the Lapiths. ... The Perrhaibians, then, having been overpowered by the Lapiths, moved for the most part to the mountain area around Pindos and the Athamanes and the Dolopes, and their land, and those of the Perrhaibians who were left behind, were taken over by the Larisaians, who lived near the Peneios and were their neighbours, cultivating

10 See Dueck (2000) 36-8, 175, Biraschi (2005) esp. 79-82. 
the most fruitful parts of the plains.

Here Strabo not only quotes Homer's description but also expands it greatly with further information, and with names - such as Perrhaibia - which do not occur in the Iliad. In his account, the displacement of the Centaurs from Pelion is part of a chain of territorial acquisitions, whose precise chronology and geography are in fact rather hard to establish. The main events mentioned appear to be as follows:

1. The lands held by the Lapiths in the Catalogue of Ships were previously held by the Perrhaibians; the Lapiths ousted the Perrhaibians and took their lands, and also pushed the Centaurs out of Pelion. These conquests were accomplished by Ixion and his son Peirithoos, the grandfather and father respectively of the Polypoites who led the Lapith contingent to Troy.

2. The Centaurs went to the Pindos region, as Homer says; Strabo adds the information that some of the displaced Perrhaibians also went westward (Dolopia and Athamania are Pindos regions between Thessaly and Epeiros).

3. However, some of the Perrhaibians remained in the Peneios region, specifically on the northern side of the river near Mount Olympos. This matches the historical reality of their location as we know it.

4. Finally, the Perrhaibians in 'historical' Perrhaibia are said to have been conquered by Larisa. Again, this tallies with discernible historical veracity. ${ }^{11}$

In addition to the greater detail, Strabo's account adds geographical components which are not present in the Catalogue of Ships. First, there are the Perrhaibians as the target of the Lapiths' conquering zeal; whereas in Homer the Lapiths only oust a single rival tribe, in Strabo's account the displacement of the Centaurs from Mount Pelion is just part of a series of aggressive moves by the Lapiths as the latter fight to establish greater and greater territorial sway in the Peneios region. This is a story about the subjection and displacement of perioikic communities, most obviously the Perrhaibians but also the early inhabitants of Magnesia, the Centaurs. ${ }^{12}$ Nothing in the account accords with the characterisation of the

\footnotetext{
${ }^{11}$ For the subordination of the Perrhaibians to the Thessalians, see n. 7.

${ }^{12}$ It should be stressed, however, that the Centaurs are not presented as the same as, or as mythically analogous to, the Magnetes: instead, the Centaurs are earlier inhabitants of Pelion who have already been driven away
} 
Lapiths and the Centaurs as symbolically opposed forces of humanity and animality, civilisation and savagery, or similar. Instead they are two tribes, one markedly more energetic and successful then the other.

This effect is enhanced by the fact that the Centaurs are typically presented as nearrelations of the Lapiths - by no means the anomalous freaks the modern reader might expect them to be. ${ }^{13}$ It is also noticeable how little interest authors display in the hybridism with which they are so strongly associated in the modern imagination. Homer calls them pheres lachnēentes - 'shaggy beasts' - giving no hint of hybrid form. Diodoros (4.70.1) establishes two physically distinct groups, successive generations: first, the Kentauroi, who mate with the mares of Pelion, and then the resulting hybrid offspring, the Hippokentauroi, who incorporate both anatomical types of their parents. Jan Bremmer argues that the concept of the Hippokentauroi emphasises that group's hybridism, ${ }^{14}$ but it is worth noting that for Diodoros' Kentauroi it has the opposite effect, that of removing any mixanthropic physical form and leaving them a tribe of humans, not differentiated from the Lapiths by anatomical peculiarity. So non-Thessalian authors are plainly interested in the motif of warring tribes, not merely in that of the destruction of inhuman monsters.

Strabo is not alone in presenting the Lapiths as territorially acquisitive. He quotes the claim of Hieronymos of Kardia that the Lapiths displaced the Pelasgoi, an indigenous people, from both Thessaly and Magnesia, and so established themselves in a great swathe of Pelasgiotis - the canton of north-east Thessaly named after the legendary indigenes. In addition, they are said to have ousted the Ainianes from the Dotion Pedion. ${ }^{15}$ Precisely how these conquests sit with the displacement of the Perrhaibians and the Centaurs is not clear, nor should we expect it to be, since we are dealing not so much with a smooth and coherent

from it by the time of the Trojan War. In the Catalogue of Ships the Magnesians send a contingent to Troy under the command of Prothoös, and their homeland is explicitly described as being around Mount Pelion and (the mouth of) the Peneios (Hom. Il. 2.756-759.)

${ }^{13}$ See e.g. Diod. Sic. 4.69. Diodoros' narrative is distinctly convoluted: Kentauros is the brother of Lapithes, and both are the sons of Apollo and Stilbe, but the Kentauroi are the offspring of the Lapith Ixion and Nephele, the cloud-woman created by Zeus. The Kentauroi mate with mares on Pelion and produce the Hippokentauroi. The relationship between Kentauros and the Kentauroi is not wholly clear; both, however, are closely linked to Lapiths. Diodoros' account follows but distorts the version in Pindar (Pyth. 2.33-48), our oldest source, in which Ixion and Nephele produce Kentauros who, mating with the Pelion mares, produce the Kentauroi. See Bremmer (2012) 30-1; Fowler (2013) 99.

${ }^{14}$ Bremmer (2012) 42.

15 Plut. Moralia 293F-4A, 297C. (For the Ainianes as earlier inhabitants of the Dotion Pedion, see Strabo 1.3.21.) 
narrative as with a range of stories clustered around a central theme: that of the Lapiths as effective conquerors of land and people.

It must be acknowledged that not all ancient authors kept as close to the Homeric version as did Strabo. Apollodoros and Diodoros appear to conflate the Thessalian myth with another Centaur story: that of Pholos, a kind of Arkadian counterpart to Cheiron in his kindliness and virtue. Like Cheiron, too, Pholos has his mountain: Pholoë, where he entertains Herakles during the latter's heroic travels. The resemblances between the Thessalian and the Peloponnesian myths are clear; it is likely that the former predated the latter, or else that local stories which had independent origins were subsequently brought into convergence because their accidental similarities seemed to encourage it. ${ }^{16}$ All such suggestions must, however, remain pure speculation. In any case, Diodoros and Apollodoros connect the two stories through the motif of flight: the displaced tribe flees from Pelion down to the Peloponnese. Apollodoros accords fundamentally with Homer in having the Lapiths drive out the Centaurs; Diodoros, by contrast (4.70.2-4), appears to make the Centaurs the chief aggressors. Under their ruler Peirithous, they initiate a conflict with the Lapiths about the territories both have inherited from their father Ixion; they end by chasing the Lapiths down to Cape Malea and harassing them triumphantly from Mount Pholoë. This reversal of the otherwise universal schema of Lapith aggression seems to be limited to Diodoros, and may in fact be the result of error or confusion. ${ }^{17}$

In general, a strong pattern is clear in the non-Thessalian literature which deals with the episode at length: it is a story of tribal displacement in which Pelion is an important place of vantage lost to or abandoned by the Centaurs. It is clear that from the external perspective certain topographical features of the Thessalian landscape are absolutely central to the myth's force and significance: Mount Pelion and the river Peneios, and the numerous settlements controlled by the Lapiths and other groups. Thessaly does not emerge as a misty otherworld, but as a place of detailed and quite realistic human and natural geography.

But does this quality derive solely from the desire of writers such as Strabo to couch their narrative in such terms, or does it reflect the formation or development of the stories within Thessaly itself?

\footnotetext{
${ }^{16}$ Padgett (2003) 21; Aston (2006) 351-3; Aston (2011) 156-8.

${ }^{17}$ For a discussion of the various sources of Diodoros' mythological material in the first five books of his Bibliotheke, see Sulimani (2011) 57-108.
} 


\section{Thessalian agency in the formation and re-formation of Lapith-Centaur myths}

It is of course no easy matter to discern the involvement of Thessalians in their own myth-formation; there are, however, a few strong indications of such involvement. We have a clear sense of the particular identification of certain Thessalian cities with the Lapith side of the story; even more clearly, the good Centaur, Cheiron, was an important component of Magnesian mythological and religious identity, showing that even Centaurs could have a role in self-representation by local communities.

Lapith associations infuse the myths of Thessaly. ${ }^{18}$ The story of their conflict with the Centaurs forms one cluster; another surrounds the god Asklepios and his mother Koronis, whose father Phlegyas and lover Ischys were both Lapiths. ${ }^{19}$ The very abundance of Lapithrelated myths and characters in Thessaly militates against seeing the stories as all externally generated; moreover, they suggest internal interest which is periodically revived, in different contexts and circumstances. I shall discuss first the possible conditions shaping the myths' creation in Archaic Thessaly, and shall then identify some signs of later Thessalian involvement in their perpetuation.

That the Catalogue of Ships itself incorporates Thessalian myth-making is highly likely. Thessaly was one of the places which produced early epic; ${ }^{20}$ it has been argued that the Catalogue itself emerged from central Greece, an origin reflected in the large amounts of space given to Boiotian, Thessalian and Phokian contingents, beyond the narrative requirements of the Iliad as a whole. ${ }^{21}$ We can thus be quite certain that the story of the Lapiths and the Centaurs embedded in the Catalogue is itself part of a body of myths first formed in Archaic Thessaly.

Though early Thessaly is inevitably hard to reconstruct, certain features of Lapith mythology are suggestive of the climate of its production. Strikingly, the city of Larisa, so

\footnotetext{
${ }^{18}$ Mili (2015) 188-90.

${ }^{19}$ Among the many ancient mentions of Koronis, her family and origins are Hesiod fr. $60 \mathrm{M}-\mathrm{W}$; Pind. Pyth. 3.811; Hom. Hymn Ascl.; Apollod. Bibl. 3.10.3. See Riethmüller (2005) vol. 1, 37-9 and 98-103.

${ }^{20}$ West (1988) argues for remnants of earlier Thessalian epic preserved within the Homeric poems. Thessaly was also probably a major driving force behind the somewhat later Catalogue of Women, and the formation of the 'Hellenic stemma': see Fowler (2013) 122-30 and 147-52.

${ }^{21}$ Kirk (1985) 178-9. For discussion of the whole Thessalian section of the Catalogue, see Hope Simpson and Lazenby (1970) 126-51; specifically on the Lapith portion, see pp. 145-8. For correspondence (and noncorrespondence) between the Catalogue and the Thessaly of any specific historical period, see Helly (1995) 7296; Morgan (2003) 102-5.
} 
dominant in Thessalian affairs from the end of the sixth century, features only slightly, and not at all in the early narratives. ${ }^{22}$ Instead, the two clusters of Lapith myth (that of Asklepios and that of the conflict with the Centaurs) have a strong geographical focus on the Dotion Pedion, an area of land on the western side of Mount Ossa, extending south to Lake Boibeis and north over the Peneios to the edge of Perrhaibia. ${ }^{23}$ Lakereia, in this zone, was the homeland of Koronis; also on the Dotion Pedion was Gyrton, the homeland of Ixion and Peirithoos. As Bruno Helly has persuasively argued, Gyrton was one of the important Archaic settlements in the area; ${ }^{24}$ it was doubtless an active producer of self-referential myths.

The Lapith affiliations of Gyrton extend beyond Ixion and Peirithoos, and beyond the conflict with the Centaurs. Gyrton was the homeland of the Lapith tribe of the Phlegyai, to which Ixion and Peirithoos belonged. ${ }^{25}$ Mythic nomenclature signals the connection between tribe and place: a female Gyrtone appears as Phlegyas' daughter (schol. Ap. Rhod. Arg. 1.57),

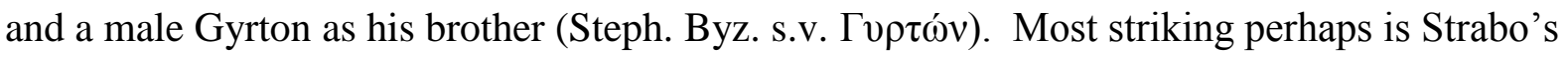
assertion that Phlegyai is an archaic name for Gyrtonians, a claim which he makes twice (9.5.21 and 7a.1.16). Like so many mythical ethne, the Phlegyai have a certain geographical flexibility, and are sometimes presented as resident in Boiotia (Hom. Hymn 3. 280; Paus. 9.36), or more rarely in Phokis (Ephoros FGrH $70 \mathrm{~F}$ 93); however, they are especially strongly linked with the Dotion Pedion, ${ }^{26}$ Gyrton specifically, and their Thessalian manifestation is probably their earliest. ${ }^{27}$

What did such mythic links mean for Gyrton? The Phlegyai (and indeed Lapiths generally) have a consistent characterisation with warlike violence and with impiety. In the Homeric Hymn to Apollo the Phlegyai are described as violent and paying no heed to Zeus; more specifically, they were considered responsible for burning the temple of Apollo at Delphi. ${ }^{28}$ So Lapith mythology does not merely articulate power-relations within Thessaly

\footnotetext{
${ }^{22}$ Apollodoros (1.8.2) uniquely cites Larisa as the original homeland of Peirithous. Cf. Ap. Rhod. Arg. 1.40-41 (a Larisaian Lapith called Polyphemos).

${ }^{23}$ For the location of the Dotion Pedion, see Helly (1987) 133-5.

24 Helly (1987).

25 Ixion was closely related to the eponym Phlegyas: his son (Eur. fr. 424) or his brother (Strabo 9.5.21).

${ }^{26}$ Once again names articulate the link: Phlegyas is the son of Ares and Dotis, who gave her name to the plain (Apollod. Bibl. 3.5.5). In addition, the Dotion Pedion, and within it especially Lakereia, are the setting of the seduction by Apollo of Phlegyas' daughter Koronis, mother of Asklepios (Hom. Hymn Ascl.; Hes. Cat. frs. 88 and 89 ).

${ }^{27}$ Fowler (2013), 365.

${ }^{28}$ Paus. 9.36.3; Pausanias comments here that the Phlegyai enjoy war more than any other Greeks.
} 
itself: it also extends to the relationship between Thessalian communities and the sanctuary at Delphi. One of the early historical drivers behind the diffusion of Lapith stories was probably the growing prominence of Thessaly at Delphi in the sixth century BC. ${ }^{29}$ It might on the face of it be supposed that the stories of vandalism and impious violence must have been created outside, and about, Thessaly - hostile projections from rivals for Amphiktyonic power. However, this is to ignore the dialogic quality of such myth-making. In fact it is certain that Thessalian communities actively espoused their Lapith identity, developing or coopting the image of the warlike, acquisitive tribe for their own symbolic advantage. ${ }^{30}$ They also participated in the Septerion, the enneateric ritual which connected Delphi with the Vale of Tempe and which commemorated a mysterious act of Thessalian violence in the Apollosanctuary. ${ }^{31}$ They were thus active participants in their own mythic characterisation.

So in origin the story of the Lapiths and the Centaurs began in an Archaic setting in which Gyrton was one of a cluster of communities in the Dotion Pedion whose influence encompassed not just adjoining regions but also the Apollo sanctuary at Delphi. However, origins are never the end of the story. Stories of tribal displacement, of territorial acquisition, did not lose their potency in changing political conditions but were re-appropriated and adapted in various ways.

Gyrton did not disappear with the rise of Larisa. Despite the failure of archaeology so far to uncover its actual remains, Gyrton emerges from other forms of evidence as a significant community in the Classical and Hellenistic period, influential both inside Thessaly and beyond. ${ }^{32}$ She coined energetically in the fourth century; the coins bear the legend $\Gamma Y P T \Omega N I \Omega N$, and bear, in addition to the equine motifs so common on Thessalian coinage, youthful male and female heads which have been identified (conjecturally) as the hero

\footnotetext{
${ }^{29}$ On the Delphic Amphiktyony in the sixth century BC, see Sánchez (2001), 466-488; Scott (2014), 71-80. For Thessalian influence in the Amphiktyony at that time, formative on the creation of early verse, see Fowler (1998), 11-12; Hall (2002), 139-154.

${ }^{30}$ For other examples of central Greek communities appropriating Lapith identity to articulate their relationship with Delphi in the Archaic period, see McInerney (1999) 165-72.

${ }^{31}$ Pind. Pae. 10 a, with discussion in Rutherford (2001) 200-5, fr. A2; Theopomp. 115 FGrH 80; Plut. Quaest. Graec. 12; De def. or. 14. For discussion of the importance of the ritual to the Thessalian communities involved, see Graninger (2009) 112-14.

${ }^{32}$ See Decourt, Nielsen, Helly et al. (2004). Gyrtonian links with Athens: Thuc. 2.22.3; IG I ${ }^{3}$ 92. Fourthcentury involvement in inter-regional sanctuaries and festivals: $F D$ 3:5.19, 47, 49, 50, 63, 61 and 76 (inclusion among the Delphic naopoioi); IG IV 2.194 (a Gyrtonian with ties to the Epidaurian Asklepieion). Hellenistic diplomatic and religious activities: SEG 47.745; IG IX 525.
} 
Gyrton and the nymph Gyrtone respectively. ${ }^{33}$ If this identification is correct, it is a clear indication of continuing interest in Lapith associations.

These associations may also have been made in one of the fragments of Souidas, a Thessalian writer probably of the third century BC, ${ }^{34}$ to whom is attributed a Thettalika. The fragment in question comes from a scholion on a line of Apollonios' Argonautika describing one of the Argonauts, Koronos the son of Kaineus:

'Koronos son of Kaineus came from wealthy Gyrton, a good man but not better than his father. For poets sing that Kaineus while still alive slew the Centaurs,' etc. Homer says, 'They lived in Gyrtone'. This is a city of Thessaly or of Perrhaibia, according to Souidas, and was named after Gyrtone the daughter of Phlegyas.

This fragment ( $F G r H 602 \mathrm{~F} \mathrm{10)}$ illustrates the perennial difficulties of establishing the words of authors like Souidas: the obvious question is how much of what is reported here was actually included in Souidas' account. Perhaps he merely mentioned Gyrton and calls it Perrhaibian; perhaps he also provided the information that was named after the daughter of Phlegyas; we cannot know. That Souidas did refer to the Lapith-Centaur myths is clear from his other fragments which will be discussed later in the chapter.

There are a few scattered signs that Gyrton was not the only Thessalian community interested in forging links with the Lapiths. One of the most striking case is that of Mopsion, another city of Pelasgiotis which appears to have derived its history from an eponymous hero, Mopsos. Of Mopsos Strabo (9.5.22) tells us that he was an Argonaut and a Lapith, and this is supported by other literary references. The Lapith Mopsos seems to appear on the fourthcentury bronze coins of Mopsion, ${ }^{35}$ a strong indicator of his importance to the community. Normally the identification of heroes on coins is extremely tendentious and problematic, but we are helped in this case by the depiction of narrative: the coins in question show a young man with a club fighting a Centaur, and given the clear evidence that Mopsos was a Lapith it is very reasonable to identify the Centaur's opponent as that hero.

\footnotetext{
${ }^{33}$ See Moustaka (1983) nos. 77 and 130; Rogers (1932) 80-3.

${ }^{34}$ For discussion of his Thessalian identity, see below p. xxx.

${ }^{35}$ See Rogers (1932) 135, fig. 221; Moustaka (1983) 73.
} 
A final possible instance takes us beyond literary evidence. The Thessalian city of Atrax, though not singled out in literature as having Lapith links, has been argued to show a significant cluster of personal names with Lapith resonances, in particular three known cases of Kaineus (out of a total of six across the Greek world), all in the third and second centuries BC. ${ }^{36}$ There are some reasons for caution in the application of this evidence: there are other uses of Kaineus outside Thessaly; ${ }^{37}$ moreover, other Lapith names occur only outside Thessaly. ${ }^{38}$ Plainly we are not dealing with an exclusive association. However, the seeming interest in the myths among individual Atragians in the Hellenistic period is certainly worth adding to our picture of the periodic reappropriation of Lapith identity by specific Thessalian communities. Like Mopsion, Atrax was situated on the course of the river Peneios which held together the various territories associated with Lapith conquests.

\section{Locating the Centaurs}

We have seen that Lapith identity - despite or even because of its associations with violence and transgression - was claimed and emphasised by at least two Thessalian communities, Gyrton and Mopsion, with the probability of other cases now lost to view. But what of the Centaurs? Are they essentially an absent group, displaced from Mount Pelion, consigned to the land of the Aithikes, no longer in the picture? ${ }^{39}$ This is their characterisation in much of the literature, but there are in fact signs in the ancient material (some faint, some very clear) that certain places within Thessaly did actually continue to have or even exploit a connection with the Centaurs.

As with the Lapiths, we seem to see faint glimpses of connections between the Centaurs and specific Thessalian locations. For example, Souidas (FGrH $602 \mathrm{~F} 4$ ) seems to associate them with a place called Amyrike, most plausibly located (though the fragment presents the usual difficulties of interpretation) in the Pindos region. ${ }^{40}$ This is in intriguing possibility:

\footnotetext{
${ }^{36}$ Decourt and Tziafalias (2007) 15-16; Mili (2015) 190.

${ }^{37}$ See $L G P N$ vols. 1, 2 and 5a. That said, the only instance which predates the Atragian examples is an Athenian Kaineus mentioned in $I G \mathrm{II}^{2} 2345$.

${ }^{38}$ For example, there are several Ixions, in various places, none of them Thessalian: see $L G P N$ vols. $1,3 \mathrm{a}$ and 5a, s.v. 'Ixion'

${ }^{39}$ Indeed, Strabo tells us that even in the land of the Aithikes they were regarded as no longer in existence: see 9.5.12.

${ }^{40}$ At first glance the fragment may seem to place Amyrike on the Dotion Pedion, but in fact two settlements seem to be referred to: first, Amyros on the Dotion Pedion, and second Amyrike, bordering Molossia. The second site is the one to which Souidas is apparently referring.
} 
that Centaur identity did attach in Souidas' day to a community in the general area to which the Centaurs were most often thought to have been driven. The inhabitants of Amyrike are described by Souidas as having had several earlier, mythological names: Leleges, Kentauroi and Hippokentauroi. Did the people of this community consider themselves descended from the Centaurs? This must remain only a conjecture, since no other evidence is forthcoming.

There is one rather tangential sign of Larisaian interest in Centaurs: the high-quality Thessalian horse type called the Kentauros (probably branded with a Centaur emblem) is thought to have been a product of Larisa. The Kentauros is listed by Lucian (Ind. 5) as one of several types of showy, expensive horse; the scholion on this passage explains that the

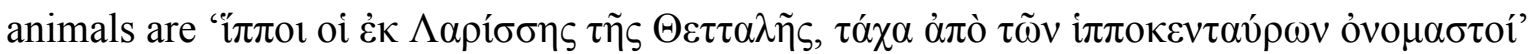
('horses from Larisa in Thessaly, surely named after the Hippokentauroi'). This is an interesting case of the famous myth being used essentially as part of a marketing strategy, and makes one wonder whether horse-breeders of the region exploited the story that the hybrid centaurs were originally the products of Pelion mares. However, it does not signify any identification of the historical community of Larisa with Centaurs: in fact, it exploits their animal aspect rather than their human one.

A far more substantial and locally important case is that of Cheiron, an unusual Centaur but a Centaur none the less, and his incorporation within the mythology and cults of a particular Magnesian community. Cheiron was famed in antiquity for characteristics of moderation and wisdom which set him apart from the other Centaurs. In most ancient accounts he is also distinguished from them by his parentage. He is typically described as the son of Kronos and Philyra (a god-nymph combination typical of heroes); the other Centaurs, by contrast, result from the unnatural union of the Lapith Ixion with the Hera-shaped cloud Nephele. However, it is surprising to find that Souidas appears to have gone against that orthodoxy, saying instead that Cheiron too was the son of Ixion, and was therefore the brother of the Centaurs ( $F G r H 602 \mathrm{~F}$ 1a and b). This has the effect of emphasising Cheiron's Centaur identity, something more usually played down by ancient writers in their attempt to emphasise his virtue. It also ties him in more closely with the Lapith mythology of Thessaly through the inclusion of the Lapith Ixion as father.

The fullest available insight into the local significance of Cheiron, however, comes not from Souidas but from a work preserved in far more sizeable fragments: the geographical writings of the third-century author Herakleides Kritikos. The extant portions of the 
periegetic work of Herakleides Kritikos, dated with most probability to between 262 and 229 BC, contain a remarkably full and detailed account of Mount Pelion, with particular attention paid to its flora, and especially the healing plants for which it was famous. In terms of myth, what emerges most strongly is the local interest in the figure of Cheiron,. In myth, many heroes were reared and educated by Cheiron in his cave-home on the mountain, Achilles and Asklepios being two who feature especially prominently in the stories of Thessaly.

Two passages of Herakleides' work reveal the ways in which Cheiron as a local mythic figure was exploited by the inhabitants of Demetrias, the city founded by Demetrios Poliorketes in $293 \mathrm{BC}$ through a process of synoecism. The first passage is as follows (FGrH 369A F 2.8):

On the topmost peak of the mountain is a cave, called the Cheironion, and a sanctuary of Zeus Aktaios to which, at the rising of the Dog Star and in the time of greatest heat, the most distinguished citizens and those in the prime of life ascend. They have been chosen in the presence of the priest, and they are wrapped round the waist with new fleeces - so great does the cold on the mountain happen to be.

There is not space here to discuss in detail the possible significance of the fleece-ritual, which in any case remains extremely obscure. ${ }^{41}$ In this context it is sufficient to note the role of the Cheironion as a vital landmark on the mountain to which a regular ritual procession brought both citizens and priest. This priest must be the priest of Zeus Akraios, based in Demetrias, who emerges from the epigraphic record as a key religious and civic figure in Hellenistic Magnesia: he is named among other officials in decrees of the Magnesian koinon, and had a steering role in the governance of the local oracle of Apollo Koropaios at Korope. ${ }^{42}$ Both the Pelion shrine and the oracle of Apollo are pre-existing institutions which acquired a new role as extra-urban sanctuaries of Demetrias, as Kravaritou has shown, part of a complex process

\footnotetext{
${ }^{41}$ For discussion, see Buxton (1992) 10-11 and (1994) 93-5; Gorrini (2006) 283-4; Aston (2011) 92-3; Mili (2015) 203. For more general discussion of Cheiron's mythic and cult role in Thessaly, see Papachatzis (1984) 136-41. For details of the cult site on Pelion, see Riethmüller (2005) 103-5.

${ }^{42}$ See e.g. IG IX 1109 and $1110-2^{\text {nd }}$ century decrees concerning the regulation of the oracle of Apollo Koropaios, in which the priest of Zeus Akraios has a prominent role. (For discussion, see Daux [1959]; Papachatzis [1960].) Also relevant are $I G I^{2} 1103,1105$ II, $1108-2^{\text {nd }}$ century decrees from Demetrias in which the priest of Zeus Akraios is named as a key official.
} 
by which local traditions were incorporated into a new political configuration which mixed Macedonian and Magnesian elements. ${ }^{43}$

There is, however, a particular dimension of the Cheiron cult, that of healing, as another fragment of Herakleides makes clear ( $F G r H 369 \mathrm{~A} \mathrm{~F} \mathrm{2.12).}$

One clan among the citizens knows this power; this clan is said to be descended from Cheiron. Father hands down and shows the power to son, and thus it is guarded, so that none other of the citizens knows it. And it is sacrilegious for those who understand the medicines to help the afflicted for payment, but they must do so for free.

Here we have a Demetrias clan specialising in the healing arts and defining themselves as descendants of Cheiron, whose own medical abilities were so intimately linked with his mountain home and its herbology. ${ }^{44}$ Historians have noted the similarity to the Asklepiadai of Kos, and in my view this is anything but coincidental. In the $3^{\text {rd }}$ century BC the Asklepios cult on Kos, which underwent an ambitious programme of expansion and self-advertising, had strong links with various communities in Thessaly and also with the ethnos of the Magnesians, as epigraphic evidence makes clear. Homolion rather than Demetrias was the Magnesian community most involved in the Koan connection. ${ }^{45}$ However, we can be sure that Magnesia as a whole would have been made keenly aware of the energy with which the Koans were prosecuting their Asklepios-cult and their claim on Asklepios as an ancestor of Koan doctors. Perhaps it was somewhat in the spirit of competition that the healers of Demetrias claimed derivation from Asklepios' teacher, the original fount of Thessalian medical wisdom.

Cheiron is a useful figure in this way, because he is the great original from which other, younger characters derive their skills and their abilities; he is also useful because he

\footnotetext{
${ }^{43}$ Kravaritou (2011) 119-22; see also Intzesiloglou (1996).

${ }^{44}$ Aston (2009) 94.

45 This is reflected in SEG 53: 850, a large stele of 242 BC recording a decree of Homolion (among other places) that asylia be formally granted to the Koan Asklepieia. See Helly (2004); Rigsby (2004) and (1996) 131-4. For general discussion of Thessaly in the third century BC, see Helly (2009). A great deal of new insight into links between Thessaly and communities of Asia Minor in this period is afforded by a recently published inscription from Aigai in Aiolia recording shared religious practices; see Malay and Ricl (2009); Parker (2011) esp. 116-18.
} 
constitutes a node linking a number of Thessalian myth-clusters, so that by claiming him a community could place itself in an influential position vis-à-vis various regional traditions. Perhaps the most wide-ranging of these was the story of Achilles and his family. Cheiron is always accorded a substantial stake in Achilles' life as the tutor who rears him following the departure of his mother Thetis; there was even a tradition which made Cheiron the father of Thetis and therefore the grandfather of Achilles. That Souidas espoused this version is suggested by the following scholion on Apollonios' Argonautika, referring to a line in the poem where the departing Argonauts are waved off by Thetis, standing on the Magnesian shore with her son Achilles in her arms.

Certain writers have disagreed about the mother of Achilles, as Lysimachos the Alexandrian says in the second book of his Nostoi, exactly as follows: 'For Souidas and Aristoteles, he who worked on Euboia and he who wrote the accounts of the Phrygians, ${ }^{46}$ and Daimachos, and Dionysios of Chalkis, have not allowed the widespread belief about Achilles to remain in place: on the contrary, some believe that he was born from Thetis the daughter of Cheiron, and Daimachos that he was born from Philomela the daughter of Aktor.

The clear implication here is that of all the authorities cited by Lysimachos, Daimachos promotes the Philomela version and so all the others (Souidas, Aristoteles and Dionysios) must have espoused the story in which Cheiron was the father of Thetis. So Souidas is not alone in giving Cheiron this special connection with Achilles (see also Hyg. Poet. Astr. 2.18). The impossibility of dating with certainty any of the other authors cited in the scholion prevents any claim that he was the originator of the variant, tempting though that theory is. None the less it is interesting to find our Thessalian author making this literary choice, a choice which wrote Cheiron even more strongly into the heart of the Aiakid mythology of Thessaly. If we are right to suppose Souidas to have been writing in the third century BC when the cult of Cheiron as healer on Pelion was influential under the aegis of Demetrias, we might see the two phenomena as connected: Cheiron's enhanced cult status encouraged his closer incorporation into the life of the region's most far-famed legendary inhabitant and

\footnotetext{
${ }^{46}$ The 'ó ... kà ò' structure seems to suggest that Souidas wrote about Euboia (in addition to his work on Thessaly) and Aristoteles about the Phrygians.
} 
literary product.

\section{Conclusion}

This chapter has illustrated of the value of enquiring into the specific conditions and circumstances which shaped the formation and development of myths in the regions where the myths are set. The Lapiths and the Centaurs are not simply emblems of a symbolic conflict that may be deployed with equal power in any Greek location, whether in literature or on the metopes of a temple. They also emerge from, and reflect, the Thessalian communities which in a sense they describe. And Thessaly itself is not a fantasy land: it had life and history of its own, and a role in shaping its own mythic narratives.

But this does not constitute an assertion that the local dimension of myth is uniquely important. It provides an alternative perspective of myth, the internal one, but it is essential not to assume a clear separation between this internal view and the external one of nonThessalian narratives. Internal and external, Thessalian and non-Thessalian, do not run along entirely separate channels. Instead, we have seen various vital intersections between the two, and it is with a brief consideration of these intersections that I conclude.

Souidas exemplifies the matter well. Souidas has made a number of appearances, inspiring each time a mixture of frustration and excitement - frustration at the scant and truncated nature of the surviving fragments, excitement because here at last is a Thessalian author. Yet caution must be applied to avoid damaging assumptions. Though it is reasonably certain that Souidas was from Thessaly, ${ }^{47}$ that does not mean that his accounts constitute the Thessalian versions of the stories he mentions. We cannot know to what extent he reflected contemporary Thessalian myth-telling, and in any case there would not have been a single Thessalian version of the stories. His accounts sometimes seem to diverge in an interesting way from what we may see as the mythographic mainstream - that is, the versions represented in the majority of written sources - but it is impossible to tell whether that is because he transmits unique local accounts or simply because he took a contrarian stance in his work.

\footnotetext{
${ }^{47}$ Souidas is certainly a particularly Thessalian name: it has fourteen entries in the LGPN (including our author), of which thirteen are Thessalian (and the fourteenth is from adjoining Ainis). One of the attestations of the name is a Gyrtonian (see $I G \mathrm{IX}^{2} 517$, dated $215 \mathrm{BC}$ ).
} 
Crucially, Souidas should not be regarded as providing a uniquely Thessalian voice, uncontaminated by the louder narratives of other regions. To see him in this light would be to ignore all that we know about writers and intellectuals in the Hellenistic period (including in Thessaly), and also to ignore clear signals in what remains of his work. His interest in Achilles is not a parochial antiquarian burrowing into local mythic versions; in fact, it may reflect a relationship outside Thessaly, with Pyrrhos of Epeiros, who like all his line claimed Aiakid descent and cultivated Thessalian ties accordingly. Souidas is sometimes mentioned in conjunction with Kineas, another Thessalian author who supposedly worked as an ambassador for Pyrrhos ${ }^{48}$ and wrote about Thessalian culture in such a way as to emphasise its Epeirote links. ${ }^{49}$ Both Souidas and Kineas in their writings seem to have connected the Epeirote sanctuary of Dodona with Thessaly by suggesting that Thessaly was the oracle's original location before it was moved to Epeiros (Souidas FGrH $602 \mathrm{~F} 11 \mathrm{a}$ and b; Kineas FGrH $603 \mathrm{~F} 2 \mathrm{a}$ and b). So it is plausible to see Souidas, like Kineas, as belonging to the historical and cultural ambit of Pyrrhos in the third century BC, and as having concerns far beyond the unearthing or preservation of local mythic curiosities. ${ }^{50}$

This is unsurprising. Writers of local myth and history were, in Hellenistic Thessaly as elsewhere, part of the network of cultural and political connections which linked the communities of that region with other parts of the Greek world. We have mentioned Kineas, writer, orator and ambassador. Another figure to note is the Bombos from the Troad who, in the mid-second century BC, was formally honoured by Larisa because he had, among other good deeds, given performances in the gymnasion in which he has recalled 'people who have been distinguished for [or among?] the Larisaians' (lines 16-17). ${ }^{51}$ Parallel inscriptions suggest that Bombos's performances made reference to mythological figures connecting Larisa and Alexandria, thus facilitating a symbolic renewal (the crucial verb ananeōmai, in Thessalian dialect, occurs on line 18) of the sungeneia and philia between the two

\footnotetext{
${ }^{48}$ Souidas and Kineas mentioned together: Strab. 7.7.12; Steph. Byz. s.v. $\Delta \omega \delta \omega ́ v \eta$. The ambassadorial role of Kineas: Plut. Pyrrh. 14, which says that the king made extensive use of Kineas' rhetorical powers, respected him highly, and attributed to him the larger part of his successes.

${ }^{49}$ It should be noted that such links were not forged out of nothing: the Molossian dynasty had traditionally allied itself with Thessalian mythology through such media as the choice of names, extending beyond the Aiakid stemma. For example, when Themistokles visited Epeiros in $466 \mathrm{BC}$ he was guest of the king Admetos, whose wife was called Phthia, both Thessaly-related names. (See Plut. Them. 24.1-3.) Euripides' Andromache articulates the Molossian claim to descent from Achilles' son Neoptolemos, and is likely to have been composed for performance in the Molossian court (see Allan [2000] 152-7). For a general discussion of relations between the Molossian dynasty and both Thessaly and Athens, see Hammond (1967) 492-507.

${ }^{50}$ On the political and social landscape of third-century Thessaly, see Helly (2009).

${ }^{51}$ Original publication: Béquignon (1935) 55-64. For full discussion of the inscription, see Helly (2006).
} 
communities. ${ }^{52}$ Local historians were absolutely not parochial figures, with purely local impact: they travelled, performed abroad, and both wielded and received important mythological influences. Though we know next to nothing about Souidas it is far more plausible to see him in the mould of a Kineas or a Bombos rather than as the conduit of untouched local traditions. Strabo's accusation that Souidas wanted to 'flatter' the Thessalians may be relevant here: this suggests a significant role in the ongoing development of regional identity (Strabo 7.7.12 = Souidas FGrH 602 F 11a). But we should also see him as porous, an educated man who must have been well versed in the literary accounts of past generations and of his present day. His participation in a strand of mythography which revised the traditional parentage of Thetis, for example, shows him to have been aware of the alternative, the 'mainstream', version, and to have shaped his own account accordingly.

Establishing where local ends and inter-regional or pan-Hellenic begins is also both impossible and unnecessary. Achilles and his circle, including Cheiron, are a good example of this. We think of them as epic characters, and indeed they are, important not only in the Homeric poems but in later works such as Apollonios' Argonautika. Epic would seem to detach them from the local dimension of production and development, but this is not so. Not only was Thessaly an influential region in the creation of early epic, ${ }^{53}$ there are also several post-Classical signs of interest by Thessalian communities, for example the deployment of such characters as Thetis on local coinage. ${ }^{54}$ However, from the Classical period onward it is impossible to be sure that Thessalians would have perceived and approached characters such as Achilles, Thetis and Cheiron as the products specifically of epic; instead, other conduits, such as prose historiography, are likely to have been in the frame. An indissoluble mixture of Thessalian and non-Thessalian sources would have prevailed, as well as a manifestation in words, images and ritual acts, and in such a situation we cannot - and should not - hope to maintain a clear distinction between the purely local and the purely external.

\footnotetext{
${ }^{52}$ Especially comparable, linguistically, thematically and chronologically, is a second century inscription found in the agora of Peloponnesian Argos in which the Argive demos honours a Cilician rhetor Publius Anteius Antiochus for having reinforced the ties of sungeneia between Argos and Cilician Aigai by recounting at Argos the myth in which Argive Perseus came to Cilicia in pursuit of the Gorgons. (SEG 26, 426 and 31, 308; Curty [1995] 13-15, no. 5.) Like Bombos, Publius Anteius Antiochus is praised for promoting paideia, and for using legendary deeds to restore cultural connections.

${ }^{53}$ West (1988).

${ }^{54}$ In particular, Larisa Kremaste in Phthiotis minted coins showing Thetis bringing armour to Achilles. See e.g. BMC Thessaly to Aitolia, pl. VIII, no. 1; Rogers (1932) 102-3.
} 


\section{Bibliography}

Allan, W. 2000. The Andromache and Euripidean Tragedy. Oxford: Oxford University Press.

Aston, E.M.M. 2006. 'The Absence of Chiron.' CQ 56: 349-362.

--- 2009. 'Thetis and Cheiron in Thessaly.' Kernos 22: 83-107.

--- 2011. Mixanthrôpoi: Animal/human Hybrid Deities in Greek Religion. Kernos

Suppl. 25. Liège: Centre International d'Étude de la Religion Grecque Antique.

Béquignon, Y. 1935. 'Études Thessaliennes, VII: Inscriptions de Thessalie.' BCH 59: 3677.

Biraschi, A.M. 2005. 'Strabo and Homer: A Chapter in Cultural History.' In Strabo's Cultural Geography, edited by D. Dueck, H. Lindsay and S. Pothecary, 73-85. Cambridge: Cambridge University Press.

Bremmer, J. 2012. 'Greek Demons of the Wilderness: The case of the Centaurs.' In Wilderness Mythologies, edited by L. Feldt, 25-53. Berlin and New York: de Gruyter. Buxton, R.G.A. 1992. 'Imaginary Greek mountains.' JHS 107: 1-15.

--- 1994. Imaginary Greece: The Contexts of Mythology. Cambridge: Cambridge University Press.

Curty, O. 1995. Les parentés legendaries entre cités grecques. Catalogue raisonné des inscriptions contenant le terme ГҮГГЕNEIA et analyse critique. Geneva: Librairie Droz.

Daux G. 1959. 'Sur les décrets de Démétrias relatifs au sanctuaire d'Apollon Coropaios $\left(\mathrm{SIG}^{3} 1157=\mathrm{IG} \mathrm{IX}^{2} 1109\right)$.' $B C H$ 83: 285-287.

Decourt, J.-C., T.H. Nielsen and B. Helly. 2004. 'Gyrton, Gyrtone.' In An Inventory of Archaic and Classial Poleis, edited by M.H. Hansen and T.H. Nielsen, 693. Oxford: Oxford University Press.

Decourt, J.-C. and A. Tziafalias. 2007. 'Mythological and Heroic Names in Atrax.' In Old and New Worlds in Greek Onomastics, edited by E. Matthews, 9-20. Oxford: Oxford University Press. 
Dueck, D. 2000. Strabo of Amasia: Greek Man of Letters in Augustan Rome. London: Routledge.

Fowler, R.L. 1998. 'Genealogical Thinking, Hesiod's Catalogue, and the Creation of the Hellenes.' PCPS 44: 1-19.

--- 2013. Early Greek Mythography, vol. 2. Oxford: Oxford University Press.

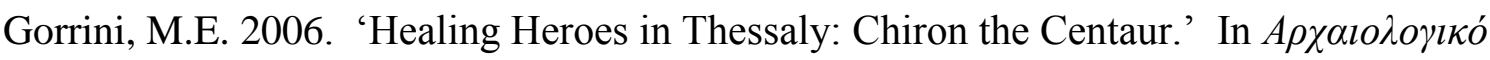

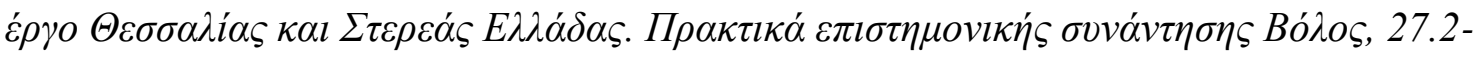

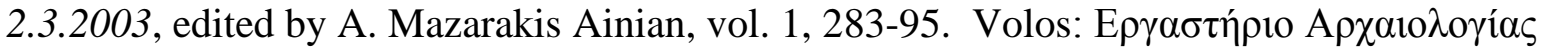

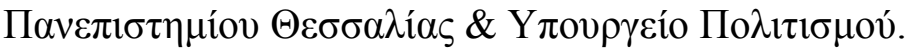

Graninger, D. 2009. 'Apollon, Ennodia and Fourth-Century Thessaly.' Kernos 22: 109-24.

--- 2011. Cult and Koinon in Hellenistic Thessaly. Leiden: Brill.

Hall, J.M. 2002. Hellenicity: Between Ethnicity and Culture. Chicago: University of Chicago Press.

Hammond, N.G.L. 1967. Epirus: the Geography, the Ancient Remains, the History and Topography of Epirus and Adjacent Areas. Oxford: Clarendon.

Hawes, G. 2014. Rationalising Myth in Antiquity. Oxford: Oxford University Press.

Helly, B. 1987. 'Le « Dotion Pedion », Lakéreia et les origines de Larisa.' JSav 3: 127-158.

--- 1995. L'État Thessalian: Aleuas le Roux, les Tétrades et les Tagoi. Lyon: Maison de l'Orient Méditerranéen.

--- 2004. 'Décrets de cités thessaliennes à Cos.' Chiron 34: 87-107.

--- 2006. "Décret de Larisa pour Bombos, fils d'Alkaios, et pour Leukios, fils de Nikasias, citoyens d'Alexandrie de Troade (ca 150 av. J.-C.).” Chiron 36: 171-203.

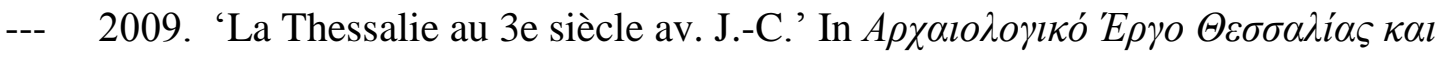

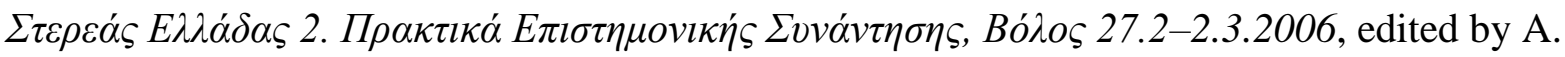

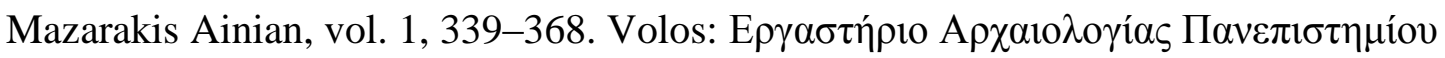

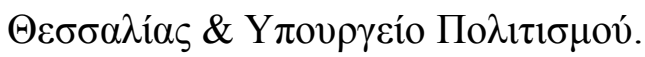


--- 2014. Géographie et Histoire des Magnètes de Thessalie I. De la plaine thessalienne aux cités de la côte égéenne (c.750 - c. 300 av. J.-C.). Sainte-Colombe-surGand: la Rumeur Libre Éditions.

Hope Simpson, R. and J.F. Lazenby. 1970. The Catalogue of Ships in Homer's Iliad. Oxford: Clarendon.

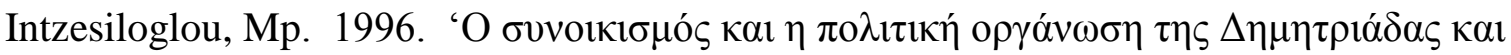

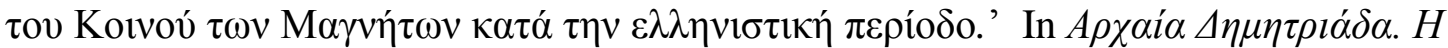

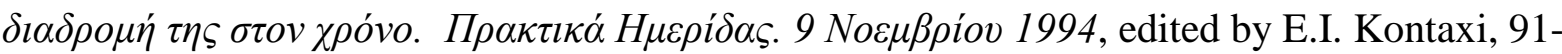

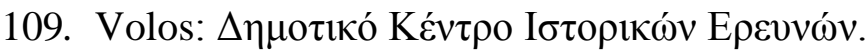

Kirk, G.S. 1985. The Iliad: a Commentary. Vol. 1: Books 1-4. Cambridge: Cambridge University Press.

Kravaritou, S. 2011. 'Synoecism and religious interface in Demetrias (Thessaly).' Kernos 24: 111-135.

Malay, H. and M. Ricl. 2009. 'Two New Hellenistic Decrees from Aigai in Aiolis,' EA 42: $39-47$.

McInerney, J.J. 1999. The folds of Parnassos: land and ethnicity in ancient Phokis. Austin: University of Texas Press.

Mili, M. 2015. Religion and Society in Ancient Thessaly. Oxford: Oxford University Press. Morgan, C. 2003. Early Greek States Beyond the Polis. London: Routledge.

Moustaka, A. 1983. Kulte und Mythen auf thessalischen Münzen. Beiträge zur Archäologie 15. Würzburg: Konrad Triltsch.

Padgett, J.M. 2003. 'Horse Men: Centaurs and Satyrs in Early Greek Art.' In The Centaur's Smile: The Human Animal in Early Greek Art, edited by J.M. Padgett, 3-46. New Haven: Yale University Press.

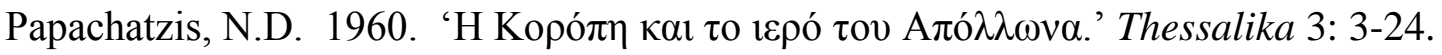

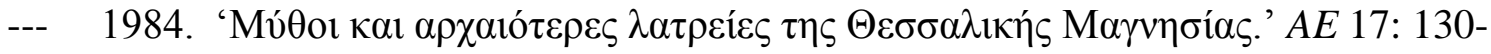
150. 
Parker, R. 2011. 'The Thessalian Olympia.' ZPE 177: 111-118.

Riethmüller, J.W. 2005. Asklepios: Heiligtümer und Kulte. 2 vols. Heidelberg: Archäologie und Geschichte.

Rigsby, K.J. 1996. Asylia: Territorial Inviolability in the Hellenistic World. Berkeley: University of California Press.

--- 2004. “'Theoroi' for the Koan Asklepieia.' In K. Höghammar ed., The Hellenistic 'Polis' of Kos: State, Economy and Culture (Uppsala), 9-14.

Rogers, E. 1932. The Copper Coinage of Thessaly. London: Spink and Sons.

Rutherford, I.C. 2001. Pindar's Paeans: A Reading of the Fragments with a Survey of the Genre. Oxford: Oxford University Press.

Sánchez, P. 2001. L’Amphictionie des Pyles et de Delphes. Stuttgart: Franz Steiner.

Scott, M. 2014. Delphi: A History of the Centre of the Ancient World. Princeton NJ: Princeton University Press.

Sprawski, S. 1999. Jason of Pherae. Electrum 3. Krakow: Jagiellonian University Press.

--- 2006. 'Thessalians and Their Neighbours in the Classical Period.' In $1^{\circ} \Delta \imath \varepsilon \theta v \varepsilon \dot{\varsigma}$

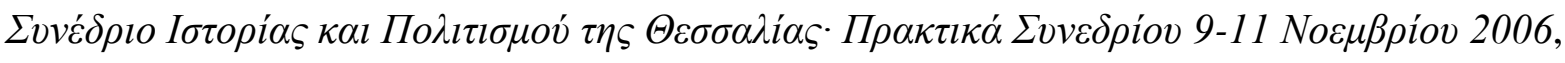

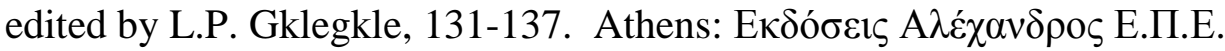

Sulimani, I. 2011. Diodorus' Mythistory and the Pagan Mission: Historiography and Culture-Heroes in the First Pentad of the Bibliotheke. Leiden: Brill.

West, M.L. 1988. 'The rise of the Greek epic.' JHS 108: 151-72. 